\title{
Regulatory mechanisms of fowl sperm motility: possible role of endogenous myosin light chain kinase-like protein
}

\author{
K. Ashizawa ${ }^{1}$, G. J. Wishart ${ }^{2}$, K. Nishinakama ${ }^{1}$, T. Sakamoto ${ }^{1}$ and \\ Y. Tsuzuki ${ }^{1}$ \\ ${ }^{1}$ Laboratory of Animal Reproduction, Faculty of Agriculture, Miyazaki University, Miyazaki 889-21, \\ Japan; and ${ }^{2}$ Department of Molecular and Life Sciences, University of Abertay Dundee, \\ Dundee DD1 1HG, UK
}

\begin{abstract}
The motility of both intact and demembranated fowl spermatozoa was vigorous at $30^{\circ} \mathrm{C}$, but decreased markedly following the addition of I-(5-chloronaphthalene-1-sulfonyl)- $1 \mathrm{H}$ hexahydro-1,4-diazepine hydrochloride (ML-9), a specific inhibitor of myosin light chain kinase (MLCK). Furthermore, the presence of a MLCK substrate peptide also inhibited the motility of demembranated spermatozoa at $30^{\circ} \mathrm{C}$. In contrast, the addition of $\mathrm{N}$-[2-(methylamino)ethyl]-5-isoquinolinesulfonamide dihydrochloride $(\mathrm{H}-8)$ or $\mathrm{N}$-(2guanidinoethyl)-5-isoquinolinesulfonamide hydrochloride (HA1004), specific inhibitors of cAMP-dependent protein kinase, did not appreciably affect the motility of either intact or demembranated spermatozoa. Cyclic AMP-dependent protein kinase substrate peptides were also ineffective for the inhibition of motility of demembranated spermatozoa at $30^{\circ} \mathrm{C}$. Immunoblotting of sperm extract, using an antibody to MLCK, revealed two major crossreacting proteins of $130 \mathrm{kDa}$ and $61-64 \mathrm{kDa}$, which corresponded to the molecular mass of MLCK. In addition, immunogold particles, which reacted with the anti-MLCK antibody, were observed around or on the axoneme at the ultrastructural level. These results suggest that the phosphorylation of axonemal protein(s) by MLCK, or a MLCK-like protein, rather than by cAMP-dependent protein kinase, may be involved in the maintenance of fowl sperm motility at $30^{\circ} \mathrm{C}$.
\end{abstract}

\section{Introduction}

There is substantial evidence that protein phosphorylationdephosphorylation plays a primary role in the second messenger regulatory mechanisms of sperm movement (for review, see Tash and Means, 1983; Brokaw, 1987; Lindemann and Kanous, 1989; Tash, 1989; Majumder et al., 1990; Morisawa, 1993, 1994; Tash and Bracho, 1994). With regard to protein dephosphorylation, it has been proposed that inhibition of mammalian sperm motility by $\mathrm{Ca}^{2+}$ may be due to the activation of protein phosphatase type $2 \mathrm{~B}$ (calcineurin), a $\mathrm{Ca}^{2+} /$ calmodulin-dependent protein phosphatase (Tash et al., 1988), and also that protein phosphatase type 1 may be involved in the inhibition of fowl sperm motility at $40^{\circ} \mathrm{C}$ (Ashizawa et al., 1994a).

However, it is well recognized that protein phosphorylation by cAMP-dependent protein kinases is involved in the activation of sperm motility (see above reviews). For example, phosphorylation of a $15 \mathrm{kDa}$ axonemal protein by a cAMPdependent protein kinase is essential for the initiation of trout sperm motility (Morisawa and Hayashi, 1985); a $55 \mathrm{kDa}$ protein that is phosphorylated in a cAMP-dependent manner is apparently related to the motility state of bovine spermatozoa

Received 22 November 1994.
(Brandt and Hoskins, 1980); axokinin, a soluble $56 \mathrm{kDa}$ phosphoprotein, seems to play a key role in mediating the cAMP response in dog spermatozoa (Tash et al., 1984, 1986); and the type II regulatory subunit of CAMP-dependent protein kinase has been identified as the major cAMP-dependent phosphoprotein in bovine spermatozoa (Noland et al., 1987; Paupard et al., 1988). Therefore, it seems likely that cAMP is indispensable for the initiation and activation of sperm motility of a variety of species (for review, see Morisawa, 1993, 1994; Tash and Bracho, 1994). However, unlike that of mammalian spermatozoa, the motility of demembranated fowl spermatozoa is not restored by the addition of cAMP at $40^{\circ} \mathrm{C}$ (Ashizawa et al., 1989a, 1992a).

Fowl spermatozoa become immotile at the avian body temperature of $40-41^{\circ} \mathrm{C}$. Motility is restored at $30^{\circ} \mathrm{C}$ or by the addition of $\mathrm{Ca}^{2+}$ at $40^{\circ} \mathrm{C}$ (Munro, 1938; Ashizawa and Nishiyama, 1978; Takeda, 1982; Ashizawa and Okauchi, 1984; Wishart and Ashizawa, 1987; Ashizawa et al., 1989b; Thomson and Wishart, 1989, 1991). $\mathrm{Ca}^{2+}$ is the major stimulatory factor in body fluids such as seminal plasma, or the fluid of the female ovarian pocket taken at the time of ovulation, in which spermatozoa can maintain their motility even at $40^{\circ} \mathrm{C}$ (Ashizawa and Wishart, 1987, 1992). In addition, the motility of demembranated fowl spermatozoa is inhibited in $\mathrm{Ca}^{2+}$-free medium at $30^{\circ} \mathrm{C}$ (Ashizawa et al., 1992b). Furthermore, the 
motility of intact spermatozoa loaded with an intracellular $\mathrm{Ca}^{2+}$ chelator, 1, 2-bis (2-aminophenoxy) ethane-N,N,N $N^{\prime} N^{\prime}$ tetraacetic acid, tetraacetoxymethyl ester (BAPTA/AM) is also negligible at $30^{\circ} \mathrm{C}$, but can be instantly restored by the subsequent addition of $\mathrm{Ca}^{2+}$ (Ashizawa et al., 1994b). Even in the presence of $\mathrm{Ca}^{2+}$, however, the addition of calmodulin antagonists such as $N$-(6-aminohexyl)-5-chloro-1naphthalenesulfonamide hydrochloride $(\mathrm{W}-7)$ and trifluoperazine inhibited the motility of intact spermatozoa at $30^{\circ} \mathrm{C}$ and $40^{\circ} \mathrm{C}$ (Ashizawa et al., 1994b). Thus, intracellular free $\mathrm{Ca}^{2+}$ seems to be essential for the maintenance of fowl sperm motility, and calmodulin is a prominent candidate as the signal transducer in $\mathrm{Ca}^{2+}$-stimulated motility. Moreover, it may be assumed that the phosphorylation by calmodulin-dependent protein kinase, rather than cAMP-dependent protein kinase, is likely to be a regulatory step in the maintenance of fowl sperm motility. However, the intracellular molecular cascades involved in the maintenance of motility remain to be determined.

In this study, attempts have been made to clarify what kind of protein kinase is involved in the regulation of fowl sperm motility. It is proposed that myosin light chain kinase (MLCK), one of the calmodulin-dependent protein kinases, or a MLCKlike protein might be involved in the maintenance of fowl sperm motility at the axonemal level.

\section{Materials and Methods}

\section{Animals and preparation of spermatozoa}

Commercial White Leghorn roosters (Babcock strain, Akagi Poultry Breeding Farm, Miyazaki) were used throughout the study. All birds were housed in individual cages and fed ad libitum on a commercial breeder diet. They were exposed to a $14 \mathrm{~h}$ light: $10 \mathrm{~h}$ dark cycle.

Semen was collected by the method of Bogdonoff and Shaffner (1954). Samples of semen pooled from four to six males were diluted approximately tenfold in $150 \mathrm{mmol} \mathrm{NaCl}$ $1^{-1}$ with $20 \mathrm{mmol}$ TES ( $N$-Tris-[hydroxymethyl]-methyl-2aminoethanesulphonic acid) $\mathrm{l}^{-1}$ at $\mathrm{pH} 7.4$ and centrifuged at $700 \mathrm{~g}$ for $13 \mathrm{~min}$ at room temperature $\left(20-25^{\circ} \mathrm{C}\right)$. The washed spermatozoa were reconstituted in the same buffer to give a final concentration of approximately $1 \times 10^{9}$ cells $\mathrm{ml}^{-1}$. Samples of 3-4 ml were poured into $30 \mathrm{ml}$ Erlenmeyer flasks with a screw cap.

\section{Chemicals}

Protein kinase inhibitors, N-[2-(methylamino)ethyl]-5isoquinolinesulfonamide dihydrochloride (H-8), $\mathrm{N}-(2-$ guanidinoethyl)-5-isoquinolinesulfonamide hydrochloride (HA1004) and 1-(5-chloronaphthalene-1-sulfonyl)-1Hhexahydro-1,4-diazepine hydrochloride (ML-9) were purchased from Seikagaku Co., Ltd (Tokyo). Protein kinase substrate peptides, Arg-Arg-Lys-Ala-Ser-Gly-Pro, Leu-Arg-Arg-Ala-SerLeu-Gly (Kemptide) and Pro-Leu-Ala-Arg-Thr-Leu-Ser-ValAla-Gly-Leu-Pro-Gly-Lys-Lys (Syntide 2) were obtained from Sigma Chemical Co. (St Louis, MO), and Lys-Lys-Arg-Pro-GlnArg-Ala-Thr-Ser-Asn-Val-Phe-Ser- $\mathrm{NH}_{2}$ was from Peninsula Laboratories, Inc. (Belmont, CA). ATP, bovine serum albumin
(BSA), 3,3'-diaminobenzidine tetrahydrochloride (DAB), dithiothreitol, potassium glutamate, TES and Triton $X-100$ were purchased from Sigma Chemical Co. Avidin-biotin peroxidase complex and protein A-gold complex were obtained from Vector Laboratories (Burlingame, CA) and Funakoshi Co., Ltd (Tokyo), respectively. SDS-PAGE molecular weight standards were purchased from Life Technologies, Inc. (Gaithersburg, MD). Calyculin A was from Wako Pure Chemical Industries, Ltd (Osaka) and other chemicals were of reagent grade from Nacalai Tesque, Inc. (Kyoto).

\section{Antibodies}

Immune mouse ascites fluid against purified fowl gizzard myosin light chain kinase (a monoclonal $\mathrm{IgG} 2 \mathrm{~b}$ ) was purchased from Sigma Chemical Co. Biotinylated anti-mouse immunoglobulins goat serum was obtained from Dako Japan (Kyoto).

\section{Measurement of motility of intact and demembranated spermatozoa}

Sperm samples were preincubated aerobically in a shaking water bath at $30^{\circ} \mathrm{C}$ or $40^{\circ} \mathrm{C}$ for $10 \mathrm{~min}$. After the preincubation, the dose-response and time course of percentage motility of intact spermatozoa were measured at $30^{\circ} \mathrm{C}$ or $40^{\circ} \mathrm{C}$ after addition of various concentrations of protein kinase inhibitors (H-8, HA1004 or ML-9). The effects of the addition of $\mathrm{CaCl}_{2}$ before the addition of inhibitors were also examined at $30^{\circ} \mathrm{C}$ and $40^{\circ} \mathrm{C}$ to be compared with those of inhibitor alone. Diluent for the measurement of intact sperm motility was the TES/ $\mathrm{NaCl}$ buffer described above.

Demembranation and reactivation of spermatozoa were performed at $30^{\circ} \mathrm{C}$ and $40^{\circ} \mathrm{C}$, according to the method described by Ashizawa et al. (1989a). The extraction medium used consisted of $0.1 \%(\mathrm{v} / \mathrm{v})$ Triton X-100, $200 \mathrm{mmol}$ sucrose $1^{-1}, 25 \mathrm{mmol}$ potassium glutamate $\mathrm{l}^{-1}, 1 \mathrm{mmol} \mathrm{MgSO}_{4} \mathrm{I}^{-1}$, $1 \mathrm{mmol}$ dithiothreitol $\mathrm{I}^{-1}$ and $20 \mathrm{mmol}$ Tris- $\mathrm{HCl}$ buffer $\mathrm{I}^{-1}$ $(\mathrm{pH}$ 7.9). The reactivation medium consisted of $0.5 \mathrm{mmol}$ ATP $\mathrm{l}^{-1}, 200 \mathrm{mmol}$ sucrose $\mathrm{l}^{-1}, 25 \mathrm{mmol}$ potassium glutamate $\mathrm{l}^{-1}$, $1.5 \mathrm{mmol} \mathrm{MgSO}_{4} \mathrm{l}^{-1}, 1 \mathrm{mmol}$ dithiothreitol $\mathrm{l}^{-1}$ and $20 \mathrm{mmol}$ Tris- $\mathrm{HCl}$ buffer $\mathrm{l}^{-1}$ ( $\mathrm{pH} 7.9$ ). To examine the effects of protein kinase inhibitors, various concentrations of H-8, HA1004 or ML-9 were added to the reactivation medium. Addition of calyculin A, a protein phosphatase inhibitor, or various protein kinase substrate peptides to demembranated spermatozoa was also performed.

The suspension of intact or demembranated spermatozoa was placed into a microscope slide chamber (Sekisui Chemical Co., Ltd, UR-157 type, Tokyo) on a thermostatically controlled warm plate, and the motility of spermatozoa was recorded by videomicroscopy (magnification on the black and white monitor was approximately $\times 600$ ) at $30^{\circ} \mathrm{C}$ or $40^{\circ} \mathrm{C}$ (Katz and Overstreet, 1981). Measurements were made on a total of 200-300 spermatozoa, distributed uniformly among the three or more fields, to determine the percentage motility.

\section{Western immunoblot analysis}

Demembranated spermatozoa were mixed with equal volumes of concentrated (twofold) Laemmli (1970) sample buffer 
and were boiled for $5 \mathrm{~min}$. Samples containing approximately $40 \mu \mathrm{g}$ protein were loaded on to $7.5 \%(\mathrm{w} / \mathrm{v})$ SDSpolyacrylamide slab gel, and electrophoresis was performed. Western blotting was performed according to the protocol of Towbin et al. (1979), but with some modifications. The proteins were transferred electrophoretically to a polyvinylidene difluoride membrane sheet (AE-6660: Atto Co., Ltd, Tokyo). After transfer, nonspecific sites on the membranes were blocked by incubating them for $1 \mathrm{~h}$ at room temperature $\left(20-25^{\circ} \mathrm{C}\right)$ in PBS containing $5 \%(\mathrm{w} / \mathrm{v})$ skimmed milk powder. The blots were then incubated overnight at $4^{\circ} \mathrm{C}$ with antibody to MLCK (1:200 dilution with $1 \%(\mathrm{w} / \mathrm{v}) \mathrm{BSA}$ in PBS). For control, the blots were incubated in PBS containing $1 \%(\mathrm{w} / \mathrm{v}) \mathrm{BSA}$ alone. The blots were further incubated for $1 \mathrm{~h}$ at $37^{\circ} \mathrm{C}$ with biotinylated anti-mouse immunoglobulins goat serum (1:100 dilution with $1 \%$ BSA in PBS) and then avidin-biotin peroxidase complex. After each incubation, the membranes were rinsed extensively in PBS containing $0.05 \%(\mathrm{v} / \mathrm{v})$ Tween 20 . Finally, $0.05 \%(\mathrm{w} / \mathrm{v}) \quad \mathrm{DAB} / 0.01 \%(\mathrm{v} / \mathrm{v}) \mathrm{H}_{2} \mathrm{O}_{2}$ solutions in $50 \mathrm{mmol}$ Tris- $\mathrm{HCl} \mathrm{l}^{-1}$ (pH 7.5) were applied to visualize the immunoreactive materials.

\section{Immunocytochemistry}

The samples of spermatozoa were routinely processed for postembedding immunogold procedures. Washed spermatozoa were centrifuged to a pellet, placed in periodate-lysineparaformaldehyde fixative (McLean and Nakane, 1974), washed with $0.1 \mathrm{~mol}$ phosphate buffer $1^{-1}$ (pH 7.4), mixed with $150 \mathrm{mmol} \mathrm{NaCl} \mathrm{l}^{-1}$ containing $1 \%(\mathrm{w} / \mathrm{v})$ agar, dehydrated through a graded series of ethanols and embedded in Lowicryl $\mathrm{K} 4 \mathrm{M}$ resin. Thin sections were collected on uncoated 200 mesh nickel grids. Thin sections were blocked by incubating them in PBS containing $1 \%(\mathrm{w} / \mathrm{v}) \mathrm{BSA}$ and then treated with antiMLCK antibody ( $1: 25$ dilution with $1 \%(w / v)$ BSA in PBS) overnight at $4^{\circ} \mathrm{C}$. The sections were further incubated for $2 \mathrm{~h}$ at room temperature $\left(20-25^{\circ} \mathrm{C}\right)$ with protein $\mathrm{A}$ conjugated approximately $10 \mathrm{~nm}$ gold particles (1:10 dilution with $1 \%$ BSA in PBS). After each incubation, the sections were rinsed extensively in PBS. The grids were stained with $5 \%(\mathrm{w} / \mathrm{v})$ uranyl acetate $/ 2 \%(\mathrm{w} / \mathrm{v})$ methyl cellulose complex solution (9:1) before examination by an electron microscope using a Hitachi $\mathrm{H}-800$ at $100 \mathrm{kV}$. Control omitting primary antibody was also performed to assess the specificity of the immunostainings.

\section{Statistical analyses}

Percentage motility was transformed using arc sine transformation. The results were analysed by ANOVA test (Snedecor and Cochran, 1980) and then by Duncan's multiple-range tests (1955).

\section{Results}

Effects of inhibitors and substrate peptides of various protein kinases on the motility of intact and demembranated fowl spermatozoa

The percentage of motility of intact spermatozoa at $30^{\circ} \mathrm{C}$ was inhibited in a dose-dependent manner by the addition of (a)

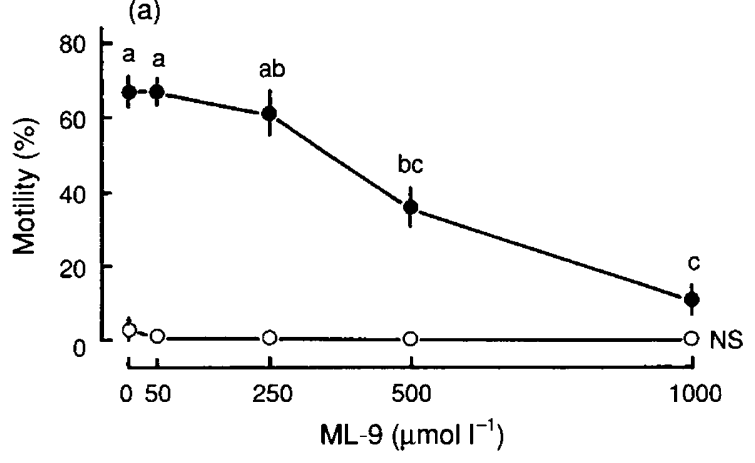

(b)

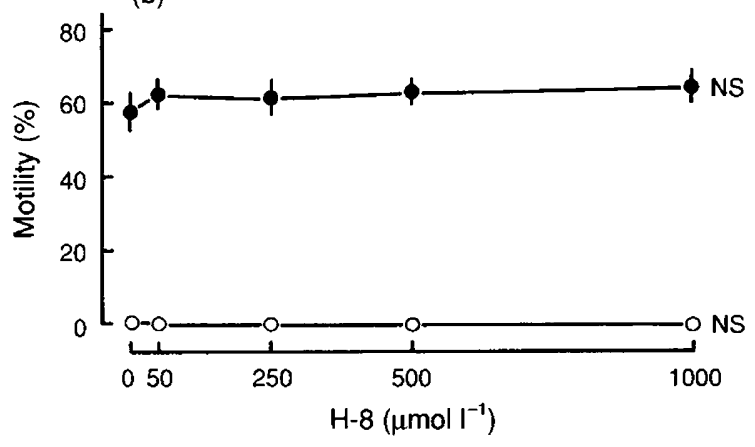

(c)

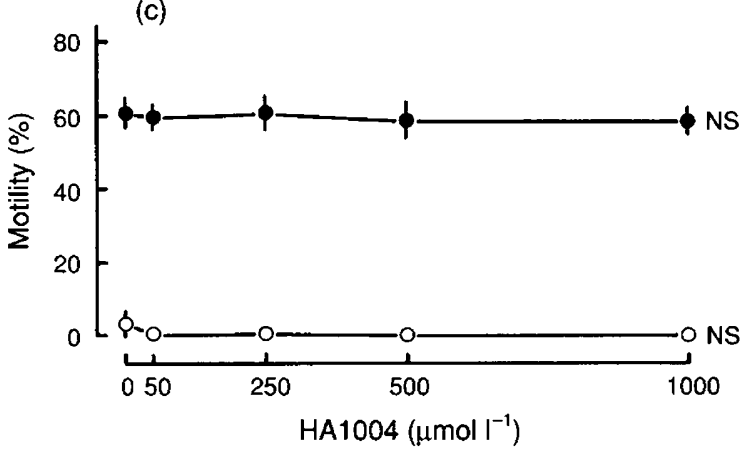

Fig. 1. Motility of intact fowl spermatozoa after addition of various concentrations of (a) ML-9, (b) H-8 and (c) HA1004 at (c) $30^{\circ} \mathrm{C}$ and (o) $40^{\circ} \mathrm{C}$. Each point represents the mean ( $\pm \mathrm{SEM}$ ) of five samples of spermatozoa. Values with different superscripts differ significantly $(P<0.01)$ from each other. NS: not significant.

ML-9, a specific inhibitor of MLCK. In contrast, no inhibition of motility was observed following the addition of the cAMPdependent protein kinase inhibitors, $\mathrm{H}-8$ or HA1004, within the range $0-1000 \mu \mathrm{mol} \mathrm{l}^{-1}$. At $40^{\circ} \mathrm{C}$, none of the above inhibitors appreciably affected the motility of intact spermatozoa, which remained almost negligible (Fig. 1).

Figure $I$ shows the motility at $30 \mathrm{~min}$ after the addition of the inhibitors. The time course of motility in the presence of $\mathrm{Ca}^{2+}$ before the addition of drugs at $30^{\circ} \mathrm{C}$ and $40^{\circ} \mathrm{C}$ is shown (Fig. 2). Even the presence of $\mathrm{Ca}^{2+}$ before the addition of ML-9 could not prevent the inhibition of motility of intact spermatozoa at $30^{\circ} \mathrm{C}$ (Fig. 2a). At $40^{\circ} \mathrm{C}$, the motility of intact spermatozoa was restored immediately after the addition of $1 \mathrm{mmol} \mathrm{CaCl}_{2} \mathrm{l}^{-1}$, but the subsequent addition of ML-9 
(a) $\mathrm{Ca}^{2+} \mathrm{ML}-9, \mathrm{H}-8, \mathrm{HA} 1004$

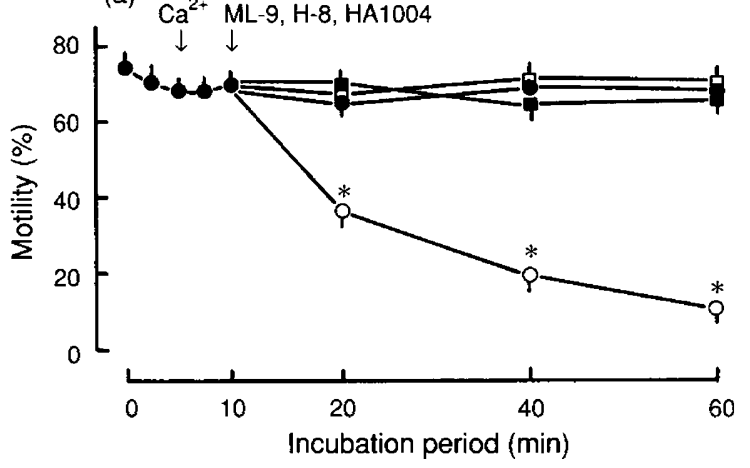

(b)

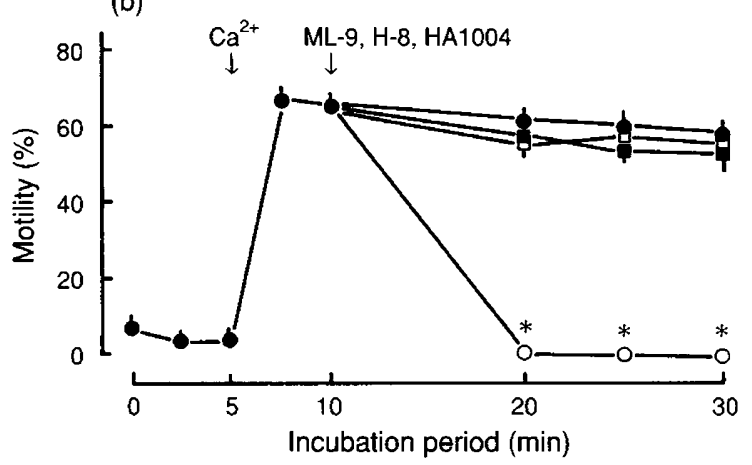

Fig. 2. Motility of intact fowl spermatozoa after addition (arrows)

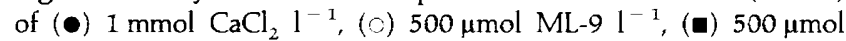

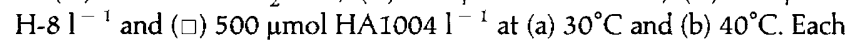
point represents the mean $( \pm \mathrm{SEM})$ of five samples of spermatozoa. Value with $*$ differs significantly $(P<0.01)$ from other three values at each period.

inhibited the motility again (Fig. 2b). In contrast, inhibition of control or $\mathrm{Ca}^{2+}$-supplemented sperm motility was not observed after the addition of $\mathrm{H}-8$ or HA1004 at $30^{\circ} \mathrm{C}$ and $40^{\circ} \mathrm{C}$

No stimulation or inhibition of motility of demembranated spermatozoa was observed following the addition of $\mathrm{H}-8$ or $\mathrm{HA} 1004$, within the range $0-1000 \mu \mathrm{mol} \mathrm{l}^{-1}$, at $30^{\circ} \mathrm{C}$ and $40^{\circ} \mathrm{C}$. In contrast, the motility of demembranated spermatozoa was markedly affected by the addition of ML-9 at $30^{\circ} \mathrm{C}$ : as the concentrations of ML- 9 were increased, the motility was reduced gradually (Fig. $3 \mathrm{a}-\mathrm{c}$ ).

Figure $3 \mathrm{a}$ shows the inhibition of motility at $5 \mathrm{~min}$ after the addition of ML-9. The effect of more prolonged exposure at $30^{\circ} \mathrm{C}$ is shown in Fig. 4. Inhibition by ML-9 was reversible, since the motility of demembranated spermatozoa could be restored by dilution (sixfold) in ML-9 free assay medium to decrease ML- 9 concentrations after $10 \mathrm{~min}$ of exposure.

The presence of the protein phosphatase inhibitor, calyculin $A$, permitted reactivation of demembranated spermatozoa at $40^{\circ} \mathrm{C}$, and this effect was maintained after addition of $\mathrm{H}-8$ or HA1004 as well as in the control (no addition). However, stimulation of motility by calyculin A was not observed by the subsequent addition of ML-9 (Fig. 5).

Furthermore, inhibition of motility of demembranated spermatozoa at $30^{\circ} \mathrm{C}$ was observed by the addition of Lys-LysArg-Pro-Gln-Arg-Ala-Thr-Ser-Asn-Val-Phe-Ser-NH ${ }_{2}$, a MLCK (a)

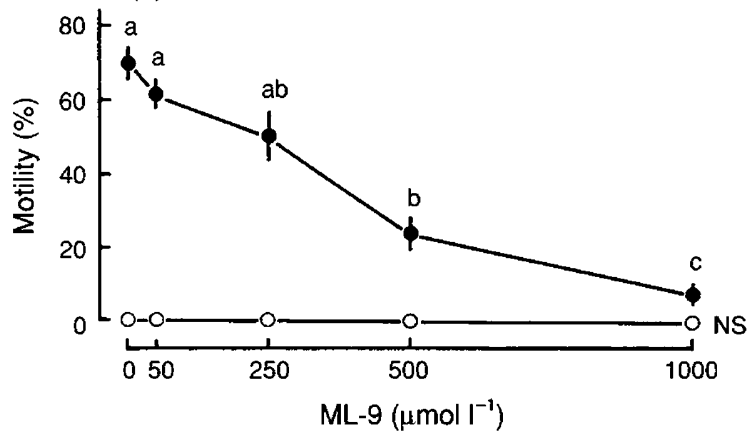

(b)

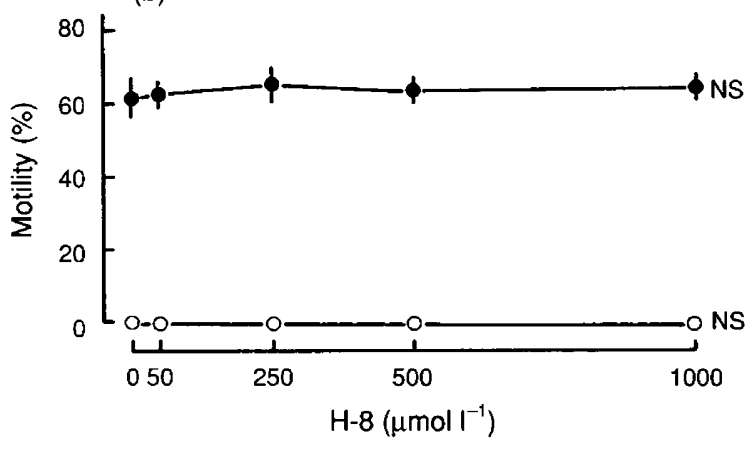

(c)

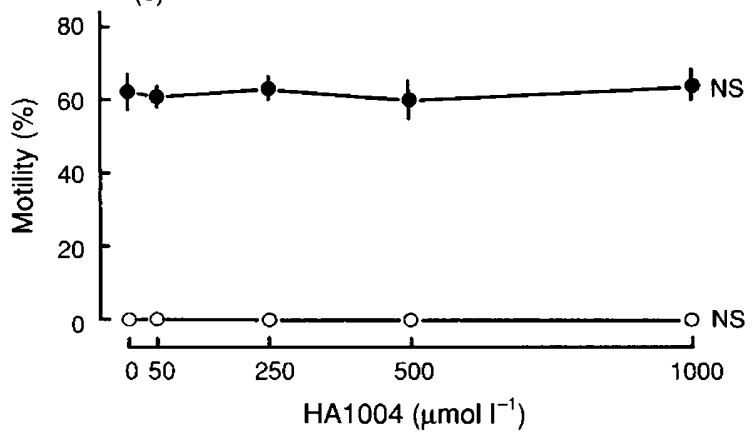

Fig. 3. Motility of demembranated fowl spermatozoa after addition of various concentrations of (a) ML-9, (b) H-8 and (c) HA1004 at (e) $30^{\circ} \mathrm{C}$ and $(0) 40^{\circ} \mathrm{C}$. Each point represents the mean ( \pm SEM) of five samples of spermatozoa. Values with different superscripts differ significantly $(P<0.01)$ from each other. NS: not significant.

substrate peptide. In contrast, the addition of Arg-Arg-Lys-AlaSer-Gly-Pro and Leu-Arg-Arg-Ala-Ser-Leu-Gly (Kemptide), cAMP-dependent protein kinase substrate peptides, or ProLeu-Ala-Arg-Thr-Leu-Ser-Val-Ala-Gly-Leu-Pro-Gly-Lys-Lys (Syntide 2), a calmodulin-dependent protein kinase II substrate peptide did not appreciably affect the motility of demembranated spermatozoa (Table 1).

Immunoblot and immunoelectron microscope identification of MLCK in fowl spermatozoa

After SDS-PAGE of sperm extracts, a band of a $82 \mathrm{kDa}$ protein was detected nonspecifically in both control and 


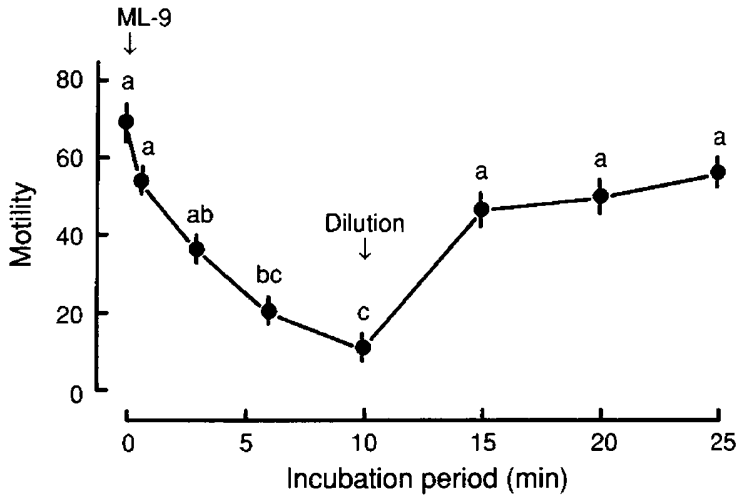

Fig. 4. The time course of motility of demembranated fowl spermatozoa after addition of $500 \mu \mathrm{mol} \mathrm{ML}-91^{-1}$ at $30^{\circ} \mathrm{C}$. The sperm sample was diluted (by a factor of approximately six; arrow) in drug-free assay medium to decrease the concentrations of the drug. Each point represents the mean ( \pm SEM) of five samples of spermatozoa. Values with different superscripts differ significantly $(P<0.01)$ from each other.

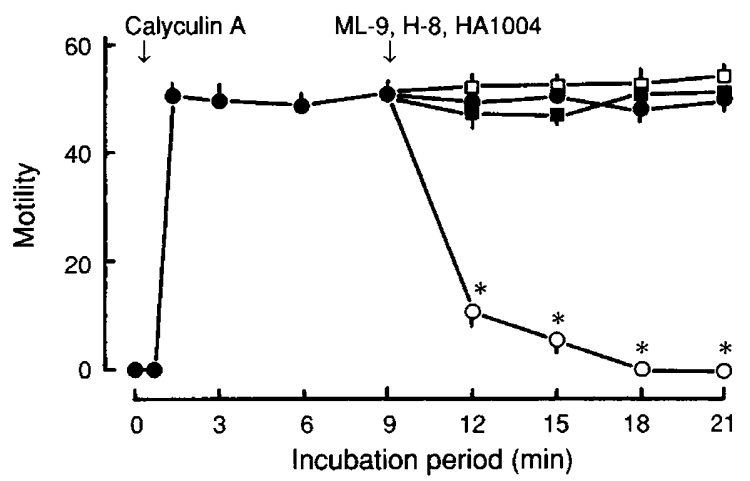

Fig. 5. Motility of demembranated fowl spermatozoa after addition

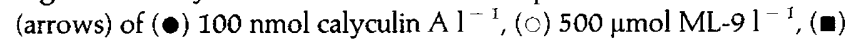

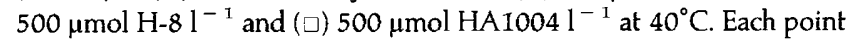
represents the mean $( \pm$ SEM) of five samples of spermatozoa. Values with ${ }^{*}$ differs significantly $(P<0.01)$ from other three values at each period.

anti-MLCK antibody-treated lanes, although the visible immunoreactive band was faint. However, bands of $130 \mathrm{kDa}$ and $6 \mathrm{I}-64 \mathrm{kDa}$ proteins were specifically recognized by the anti-MLCK antibody (denoted by the arrows in Fig. 6).

Immunolabelling with the anti-MLCK antibody showed a light distribution of gold particles around or on the axoneme at the ultrastructural level (Fig. 7), whereas no appreciable particles were detected in the control.

\section{Discussion}

Substantial evidence suggests a role for cAMP and cAMPdependent protein kinase as positive effectors for the activation of sperm motility (for review, see Tash and Means, 1983; Brokaw, 1987; Lindemann and Kanous, 1989; Tash, 1989; Majumder et al., 1990). Tash et al. (1986) reported that reactivation of the motility of demembranated dog spermatozoa produced by ATP alone is inhibited by $\mathrm{H}-8$, a specific inhibitor of cAMP-dependent protein kinase; half-maximal inhibition of motility is achieved with $50 \mu \mathrm{mol}$ drug $\mathrm{I}^{-1}$. A heat-stable protein inhibitor of cAMP-dependent protein kinase, purified from rabbit skeletal muscle or rat testis, also inhibits reactivation of demembranated mammalian and sea urchin spermatozoa (Ishiguro et al., 1982; Tash et al., 1984). Thus, the reactivation of sperm motility of a variety of species may be entirely dependent on cAMP-dependent protein phosphorylation (Tash, 1989).

However, the motility of demembranated fowl spermatozoa was not restored by the addition of cAMP at $40^{\circ} \mathrm{C}$, even though spermatozoa are usually immotile at this temperature (Ashizawa et al., 1989a, 1992a). Moreover, the present study showed that the addition of even 1 mmol H-8 or HAIOO4 $1^{-1}$ did not appreciably affect the motility of either intact or demembranated fowl spermatozoa at $30^{\circ} \mathrm{C}$. Cyclic AMPdependent protein kinase substrate peptides were also ineffective as inhibitors of the motility of demembranated spermatozoa at $30^{\circ} \mathrm{C}$. In contrast, the motility of intact and demembranated spermatozoa at $30^{\circ} \mathrm{C}$ decreased considerably after the addition of ML-9, a specific inhibitor of MLCK. Furthermore, the presence of a MLCK substrate peptide caused inhibition of the motility of demembranated spermatozoa at $30^{\circ} \mathrm{C}$, while syntide 2 , a calmodulin-dependent protein kinase II substrate peptide, did not. These results suggest that the protein phosphorylation of axonemal protein(s) by MLCK or MLCK-like protein, rather than by CAMP-dependent protein kinase, may be dominant in the involvement for the maintenance of fowl sperm motility at $30^{\circ} \mathrm{C}$.

It has been shown that MLCK, a Ca ${ }^{2+} /$ calmodulin-dependent protein kinase, is localized in the various types of non-muscle and muscle cells and there is evidence that it is involved in the regulation of cell motility by $\mathrm{Ca}^{2+} /$ calmodulin (Guerriero et al., 1981). Preliminary results from Tash's laboratory have demonstrated that mammalian spermatozoa contain MLCK, as assessed by immunofluorescence microscopy and by immunoblots of electrophoretically separated sperm proteins, providing preliminary evidence for a role of MLCK in mediating flagellar motility, consistent with its presence in flagella (Tash and Means, 1983). The data reported here show that endogenous MLCK or a MLCK-like protein may also be present in fowl sperm axoneme, since immunogold particles that reacted with the anti-MLCK antibody were observed around and on the axoneme at the ultrastructural level, even though the reaction deposits were scattered. In addition, immunoblotting of sperm extract using an antibody to MLCK revealed major crossreacting proteins of $130 \mathrm{kDa}$ and $61-64 \mathrm{kDa}$. The molecular mass of MLCK from various fowl tissues including brain, heart, skeletal muscle and gizzard is estimated to be approximately $130 \mathrm{kDa}$ (Guerriero et al., 1981). Proteolysis of the $130 \mathrm{kDa}$ MLCK from fowl gizzard produces a $64 \mathrm{kDa}$ fragment that neither binds to $\mathrm{Ca}^{2+} /$ calmodulin nor exhibits catalytic activity, and a $61 \mathrm{kDa}$ peptide that is active in the absence of $\mathrm{Ca}^{2+} /$ calmodulin (data sheet of Sigma Immuno Chemicals). In the present work, immunoreactive proteins in fowl spermatozoa corresponding to both molecular weight ranges have been found.

If MLCK, or MLCK-like protein, affects the maintenance of fowl sperm motility, then the question of its target and precise mechanisms of action is raised. Myosin, a substrate for MLCK, has been identified in bovine spermatozoa (Tamblyn, 1981), 
Table 1. Effects of protein kinase substrate peptides on the motility of demembranated fowl spermatozoa at $30^{\circ} \mathrm{C}$

\begin{tabular}{lc}
\hline Peptide & Motility (\%) \\
\hline $\begin{array}{l}\text { None (control) } \\
\text { Lys-Lys-Arg-Pro-GIn-Arg-Ala-Thr-Ser-Asn-Val-Phe-Ser-NH }\end{array}$ & $68.5 \pm 3.1^{\mathrm{a}}$ \\
$\quad$ (MLCK substrate) & $5.1 \pm 1.0^{\mathrm{b}}$ \\
$\begin{array}{l}\text { Pro-Leu-Ala-Arg-Thr-Leu-Ser-Val-Ala-Gly-Leu-Pro-Gly-Lys-Lys } \\
\quad \text { (Syntide 2; calmodulin-dependent kinase II substrate) }\end{array}$ & $56.4 \pm 4.8^{\mathrm{a}}$ \\
$\begin{array}{l}\text { Arg-Arg-Lys-Ala-Ser-Gly-Pro } \\
\quad \text { (cAMP-dependent kinase substrate) }\end{array}$ & $63.4 \pm 2.0^{\mathrm{a}}$ \\
$\begin{array}{l}\text { Leu-Arg-Arg-Ala-Ser-Leu-Gly } \\
\text { (Kemptide; cAMP-dependent kinase substrate) }\end{array}$ & $70.3 \pm 4.2^{\mathrm{a}}$ \\
\hline
\end{tabular}

Each peptide added in the reactivation medium was $0.4 \mathrm{mmol} \mathrm{I}^{-1}$. Each value represents the mean ( \pm SEM) of five samples of spermatozoa. Values with different superscripts differ significantly $(P<0.01)$ from each other.

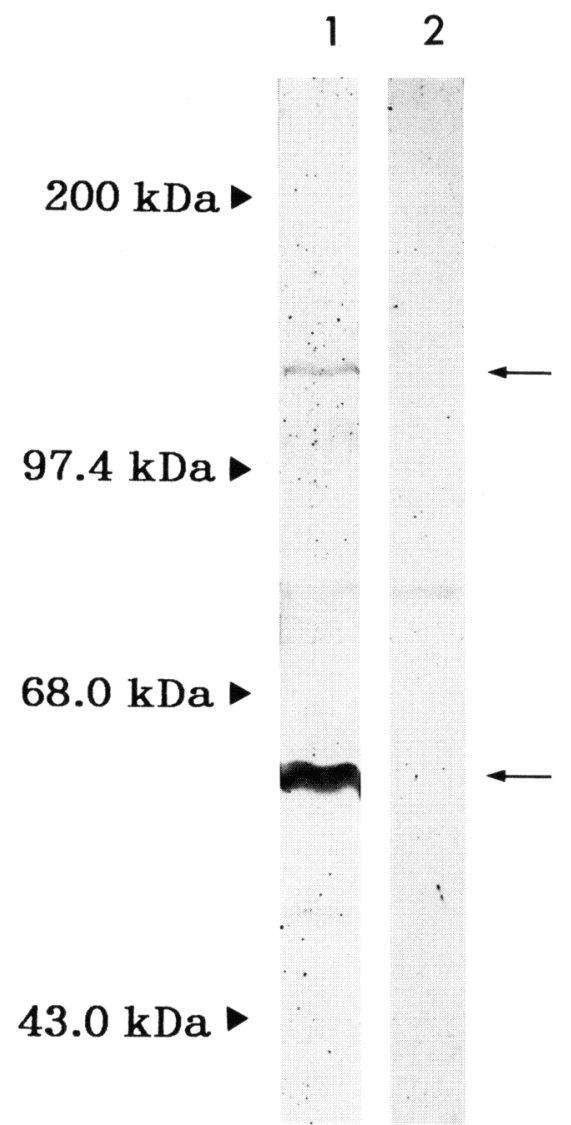

Fig. 6. Immunoblot analysis of fowl sperm myosin light chain kinase (MLCK). Lane 1: incubation with monoclonal antibody against purified fowl gizzard MLCK; lane 2: control.

and it has been localized in the neck region of human spermatozoa (Virtanen et al., 1984). Myosin is also detected on the mitochondrion and in the tail of ascidian spermatozoa (Lambert and Lambert, 1984). However, until now there has been no demonstration of its presence in fowl spermatozoa. Additional studies are therefore necessary to examine whether myosin is present in fowl spermatozoa and which proteins, i.e.,

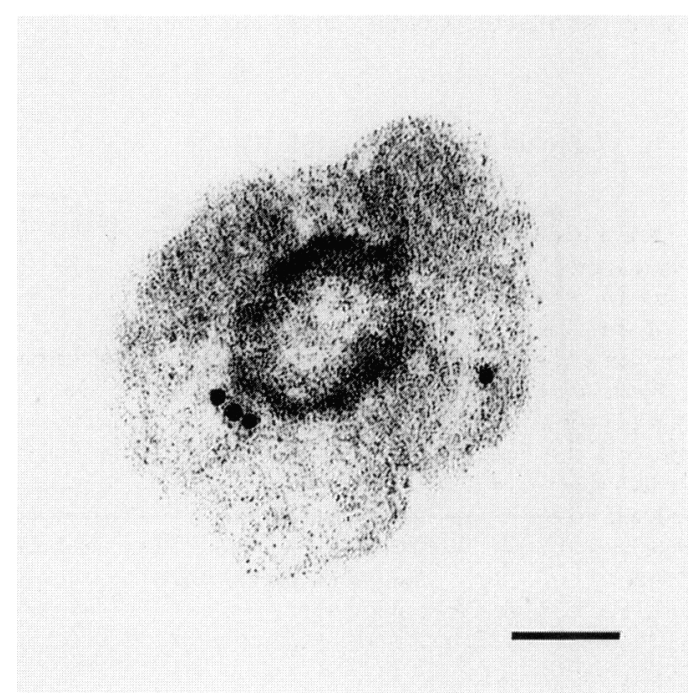

Fig. 7. Electron micrograph of immunogold staining of fowl spermatozoa. Immunogold particles are present around or on the axoneme treated with anti-MLCK antibody. Scale bar represents $0.1 \mu \mathrm{m}$.

myosin and other axonemal proteins, are phosphorylated by MLCK or a MLCK-like protein during the activation of fowl sperm motility.

Using immunoelectron microscopy, Yamamoto (1985) reported that reaction deposits against anti-calmodulin antibody are observed, on the cytoplasmic surface of plasma membrane, the outside of fibrous sheath and along the axial filaments of the guinea-pig sperm tail. It was assumed in the present study that most of the free calmodulin in fowl spermatozoa is located in the soluble fraction after demembranation and not retained in the axoneme, since inhibition of motility of demembranated spermatozoa was not observed by the addition of calmodulin antagonists such as W-7 and trifluoperazine (Ashizawa et al., 1994b). However, it is possible that some calmodulin molecules may be bound to substrate proteins such as MLCK within the axoneme, since the presence of ML-9 or MLCK substrate peptide inhibited the motility of demembranated spermatozoa. 
It is suggested that protein phosphatase type 1 , present in the fowl sperm axoneme, may be involved in the inhibition of fowl sperm motility at $40^{\circ} \mathrm{C}$, since, in addition to calyculin A and okadaic acid, inhibitors $\mathrm{I}$ and 2, specific inhibitors of protein phosphatase type $\mathrm{I}$ (Cohen, 1989), also stimulated the motility of demembranated spermatozoa at $40^{\circ} \mathrm{C}$ (Ashizawa et al., 1994a). In the study reported here, demembranated fowl spermatozoa, stimulated by the addition of calyculin $\mathrm{A}$ at $40^{\circ} \mathrm{C}$, lost their motility by the subsequent addition of ML-9, but not by the addition of H-8 or HA1004. These results suggest that the motility of fowl spermatozoa may be regulated by a balance of the phosphorylation-dephosphorylation system of axonemal proteins, which is affected by endogenous MLCK or MLCK-like protein and protein phosphatase type 1 .

G. J. Wishart was supported by the Royal Society of Edinburgh. This study was supported by a Grant-in-Aid for Scientific Research from the Ito Memorial Foundation and by a grant from the Ministry of Education, Science and Culture, Japan (No. 06660360).

\section{References}

Ashizawa K and Nishiyama $\mathbf{H}$ (1978) Effects of temperature on the vigour of motility, oxygen consumption and duration of motility of fowl spermatozoa under aerobic conditions Japanese Poultry Science 15 264-266

Ashizawa K and Okauchi K (1984) Stimulation of sperm motility and oxygen consumption of fowl spermatozoa by a low molecular weight fraction of seminal plasma Journal of Reproduction and Fertility 71 593-598

Ashizawa K and Wishart GJ (1987) Resolution of the sperm motility-stimulating principle of fowl seminal plasma into $\mathrm{Ca}^{2+}$ and an unidentified low molecular weight factor Journal of Reproduction and Fertility 81 495-499

Ashizawa K and Wishart GJ (1992) Factors from fluid of the ovarian pocket that stimulate sperm motility in domestic hens Journal of Reproduction and Fertility $95855-860$

Ashizawa K, Suzuki Y and Okauchi K (1989a) Flagellar movement in demembranated preparations of ejaculated fowl spermatozoa Journal of Reproduction and Fertility 86 263-270

Ashizawa K, Maeda S and Okauchi K (1989b) The mechanisms of reversible immobilization of fowl spermatozoa at body temperature Journal of Reproduction and Fertility 86 271-276

Ashizawa K, Katayama S and Tsuzuki Y (1992a) Regulation of flagellar motility by temperature-dependent phosphorylation of a $43 \mathrm{kDa}$ axonemal protein in fowl spermatozoa Biochemical and Biophysical Research Communications 185 740-745

Ashizawa K, Hashiguchi A and Tsuzuki Y (1992b) Intracellular free $\mathrm{Ca}^{2+}$ concentration in fowl spermatozoa and its relationship with motility and respiration in spermatozoa Journal of Reproduction and Fertility 96 395-405

Ashizawa K, Wishart GJ, Tomonaga H, Nishinakama K and Tsuzuki Y (1994a) Presence of protein phosphatase type $\mathbf{I}$ and its involvement in temperaturedependent flagellar movement of fowl spermatozoa FEBS Letters $\mathbf{3 5 0}$ 130-134

Ashizawa K, Tomonaga H and Tsuzuki Y (1994b) Regulation of flagellar motility of fowl spermatozoa: evidence for the involvement of intracellular free $\mathrm{Ca}^{2+}$ and calmodulin Joumal of Reproduction and Fertility 101 265-272

Bogdonoff PD, Jr and Shaffner CS (1954) The effect of $\mathrm{pH}$ on in vitro survival, metabolic activity, and fertilizing capacity of chicken semen Poultry Science $33665-669$

Brandt $H$ and Hoskins DD (1980) A cAMP-dependent phosphorylated motility protein in bovine epididymal sperm Journal of Biological Chemistry $\mathbf{2 5 5}$ 982-987

Brokaw CJ (1987) Regulation of sperm flagellar motility by calcium and cAMP-dependent phosphorylation Journal of Cellular Biochemistry 35 175-184

Cohen P (1989) The structure and regulation of protein phosphatases Annual Review of Biochemistry 58 453-508

Duncan DB (1955) Multiple range and multiple $F$ tests Biometrics 11 I-42
Guerriero V, Jr, Rowley DR and Means AR (1981) Production and characterization of an antibody to myosin light chain kinase and intracellular localization of the enzyme Cell 27 449-458

Ishiguro K, Murofushi $\mathbf{H}$ and Sakai H (1982) Evidence that cAMP-dependent protein kinase and a protein factor are involved in reactivation of Triton $X-100$ models of sea urchin and starfish spermatozoa Journal of Cell Biology $92777-782$

Katz DF and Overstreet JW (1981) Sperm motility assessment by videomicrography Fertility and Sterility 35 188-193

Laemmli UK (1970) Cleavage of structural proteins during the assembly of the head of bacteriophage $\mathrm{T}_{4}$ Nature 227 680-685

Lambert CC and Lambert G (1984) The role of actin and myosin in ascidian sperm mitochondrial translocation Developmental Biology 106 307-314

Lindemann CB and Kanous KS (1989) Regulation of mammalian sperm motility Archives of Andrology 23 1-22

McLean IW and Nakane PK (1974) Periodate-lysine-paraformaldehyde fixative: a new fixative for immunoelectron microscopy Journal of Histochemistry and Cytochemistry 22 1077-1083

Majumder GC, Dey CS, Haldar S and Barua M (1990) Biochemical parameters of initiation and regulation of sperm motility Archives of Andrology 24 287-303

Morisawa M (1993) Regulatory mechanisms of sperm motility. In Biology of the Sperm Line. In Animal to Man pp 81-93 Eds H Mohri, M Takahashi and C Tachi. Japan Scientific Societies Press, Tokyo

Morisawa M (1994) Cell signaling mechanisms for sperm motility Zoological Science 11 647-662

Morisawa M and Hayashi H (1985) Phosphorylation of a $15 \mathrm{~K}$ axonemal protein is the trigger initiating trout sperm motility Biomedical Research 6 $181-184$

Munro SS (1938) Fowl sperm immobilization by a temperature-media interaction and its biological significance Quarterly Journal of Experimental Physiology 27 281-287

Noland TD, Abumrad NA, Beth AH and Garbers DL (1987) Protein phosphorylation in intact bovine epididymal spermatozoa: identification of the type II regulatory subunit of cyclic adenosine $3^{\prime}, 5^{\prime}$-monophosphate-dependent protein kinase as an endogenous phosphoprotein Biology of Reproduction 37 $171-180$

Paupard MC, Macleod J, Wasco W and Orr GA (1988) Major 56,000-dalton, soluble phosphoprotein present in bovine sperm is the regulatory subunit of a type II cAMP-dependent protein kinase Journal of Cellular Biochemistry 37 $161-175$

Snedecor GW and Cochran (1980) In Statistical Methods, 7th Edition pp 215-237. Iowa State University Press, Ames

Takeda A (1982) Studies on reversible inactivation of cock spermatozoa by temperature. I. Effects of several factors on reversible inactivation Japanese Poultry Science 19 26-36

Tamblyn TM (1981) Evidence for nonmuscle myosin in bovine ejaculated spermatozoa Gamete Research 4 499-506

Tash IS (1989) Protein phosphorylation: the second messenger signal transducer of flagellar motility Cell Motility and the Cytoskeleton 14 332-339

Tash JS and Bracho GE (1994) Regulation of sperm motility: emerging evidence for a major role for protein phosphatases Journal of Andrology 15 505-509

Tash JS and Means AR (1983) Cyclic adenosine 3', 5' monophosphate, calcium and protein phosphorylation in flagellar motility Biology of Reproduction $\mathbf{2 8}$ 75-104

Tash JS, Kakar SS and Means AR (1984) Flagellar motility requires the cAMPdependent phosphorylation of a heat-stable NP-40-soluble $56 \mathrm{kd}$ protein, axokinin Cell 38 551-559

Tash IS, Hidaka H and Means AR (1986) Axokinin phosphorylation by cAMPdependent protein kinase is sufficient for activation of sperm flagellar motility Journal of Cell Biology 103 649-655

Tash JS, Krinks M, Patel J, Means RL, Klee CB and Means AR (1988) Identification, characterization, and functional correlation of calmodulindependent protein phosphatase in sperm Journal of Cell Biology 106 1625-1633

Thomson MF and Wishart GJ (1989) Elucidation of the mechanism responsible for the temperature-dependent reversible inactivation of the motility of fowl spermatozoa British Pouliry Science 30 687-692

Thomson MF and Wishart GJ (1991) Temperature-mediated regulation of calcium flux and motility in fowl spermatozoa Journal of Reproduction and Fertility $93 \quad 385-391$ 
Towbin H, Staehelin T and Gordon J (1979) Electrophoretic transfer of proteins from polyacrylamide gels to nitrocellulose sheets: procedure and some applications Proceedings of the National Academy of Sciences USA 764350 4354

Virtanen I, Badley RA, Paasivuo R and Lehto V-P (1984) Distinct cytoskeletal domains revealed in sperm cells journal of Cell Biology 99 1083-1091
Wishart GJ and Ashizawa K (1987) Regulation of the motility of fowl spermatozoa by calcium and cAMP journal of Reproduction and Fertility $\mathbf{8 0}$ $607-611$

Yamamoto N (1985) Immunoelectron microscopic localization of calmodulin in guinea pig testis and spermatozoa Acta Histochemica et Cytochemica 18 199-211 